\title{
Penatalaksanaan Anestesi untuk Seksio Sesarea pada Multigravida dengan Kardiomiopati Peripartum
}

\author{
Purwoko, Andi Rizki Caprianus \\ Bagian Anestesiologi dan Terapi Intensif RSUD DR Moewardi, Surakarta
}

\begin{abstract}
Abstrak
Peripartum Cardiomyopathy (PPCM) merupakan salah satu jenis kardiomiopati dilatasi tanpa diketahui penyebabnya yang terjadi pada wanita hamil usia reproduktif yang jarang terjadi. Patofisiologi PPCM masih kontroversial, penyebab PPCM tidak bisa dijelaskan dengan etiologi tunggal, karena memiliki penyebab multifaktor. Pasien wanita, 43 tahun, ASA III dengan preeklamsi berat pada multigravida hamil preterm belum dalam persalinan dengan PPCM NYHA II riwayat seksio sesarea 10 tahun rencana dilakukan re-seksio sesarea elektif. Pada pasien ini didapatkan pada pemeriksaan kardiovaskuler dengan murmur pansistolik. Ekokardiografi ventrikel kiri dilatasi, kontraktilitas ventrikel kiri menurun ejection fraction 31\%, fungsi diastolik restriktif, mitral regurgitasi ringan. Rencana dilakukan anestesi dengan teknik epidural namun dalam pelaksanaannya gagal epidural kemudian dikonversi menjadi anestesi umum intubasi oral. Secara umum, target hemodinamik pada berbagai teknik anestesi adalah sama, yaitu mengurangi kardiak preload dan afterload serta mencegah penurunan kontraktilitas kardiak yang sudah buruk sebelumnya. Teknik anestesi yang menghasilkan penurunan mendadak pada tahanan pembuluh darah sistemik sebaiknya dihindari. Manajemen anestesi pada pasien dengan PPCM, teknik regional anestesi maupun anestesi umum dapat diterapkan. Namun tetap mempertimbangkan beberapa faktor seperti kondisi pasien dan kemampuan dari dokter anestesi itu sendiri.
\end{abstract}

Kata Kunci: anestesi regional epidural; umum; kardiomiopati; peripartum; seksio sesaria

\section{Anesthetic Management for Caesarean Section in Multygravida with Peripartum Cardiomyopathy}

\begin{abstract}
Peripartum Cardiomyopathy (PPCM) is one type of dilated cardiomyopathy without known cause in pregnant women in reproductive age are rare. Pathophysiology of PPCM is still controversial, the cause of PPCM can not be explained by a single etiology because it has multifactor. Female patient, 43 years, ASA III with severe preeclamsia pregnancy, preterm, multigravida and not yet in labor with PPCM NYHA II and history of caesarian section 10 years ago planned for elective re-caesarian section. In this patient was obatained pansistolic murmur on cardiovascular examination. Echocardiography was obtained dilated left ventricle, left ventricular contractility decrease with ejection fraction $31 \%$, restrictive diastolic function, mild mitral regurgitation. Planned for anesthesia with epidural technique but in implementation the epidural was fail then converted into general anesthesia oral intubation. In general, hemodynamic targets in anesthesia techniques are the same, ie reducing cardiac preload and afterload and preventing a decline in bad cardiac contractility. Anesthesia techniques that produce a sudden decrease in systemic vascular resistance should be avoided. Anesthesia management in patient with PPCM both regional and general anesthesia technique can be applied. But still considering several factors such as patient's condition and the ability of the anesthesiologist itself.
\end{abstract}

Key word: anesthesia regional epidural; general anesthesia peripartum cardiomyopathy; caesarean section 


\section{Pendahuluan}

Peripartum Cardiomyopathy (PPCM) merupakan salah satu jenis dilated cardiomyopathy tanpa diketahui penyebabnya yang terjadi pada wanita hamil usia reproduktif yang jarang terjadi. PPCM memiliki angka kejadian yang rendah, $0.1 \%$ dari kehamilan, tetapi memiliki morbiditas dan mortalitas yang tinggi berkisar antara $7-50 \%$. Pada beberapa pasien, status klinis dan ekokardiografi membaik secara cepat dan bisa kembali ke kondisi normal, tetapi pada pasien lain bisa memburuk secara cepat meski sudah mendapat perawatan medis. Patofisiologi PPCM masih kontroversial, penyebab PPCM tidak bisa dijelaskan dengan etiologi tunggal, karena memiliki penyebab multifaktor. ${ }^{1}$ Peripartum Cardiomyopathy (PPCM) didefinisikan sebagai gagal jantung yang muncul antara bulan terakhir kehamilan dan 5 bulan setelah melahirkan, tidak diketahui penyebabnya, tidak ada riwayat penyakit jantung sebelum bulan terakhir kehamilan, dan adanya disfungsi sistolik ventrikel kiri yang ditunjukkan dengan kriteria ekokardiografi klasik. Pada tahun 2010, the European Society of Cardiology Working Group on PPCM mengusulkan modifikasi terhadap definisi PPCM yang sudah ada yaitu PPCM didefinisikan sebagai kardiomiopati idiopatik yang muncul sebagai gagal jantung akibat disfungsi sistolik ventrikel kiri pada akhir kehamilan atau beberapa bulan setelah persalinan tanpa ditemukannya penyebab gagal jantung. ${ }^{1-2}$ Beberapa faktor risiko telah diidentifikasi seperti: usia tua saat hamil, multiparitas, gemelli, preeklamsia, hipertensi gestasional, tokolisis jangka panjang, ras Afrika, penyalahgunaan kokain, infeksi enterovirus, defisiensi Selenium, penggunaan obat-obatan persalinan preterm (terbutaline $>4$ minggu, penggunaan jangka lama ritodrine, kombinasi obat-obatan persalinan preterm), zat beracun (kemoterapi), riwayat keluarga dengan PPCM, Guillain-Barre neuropati, miokarditis. ${ }^{2}$

Wanita dengan PPCM memiliki tanda dan gejala seperti gagal jantung. Gejala yang muncul sesak nafas, batuk, ortopnoe (sesak nafas saat berbaring), paroksismal nokturnal dyspnea (sesak nafas pada malam hari), kelelahan, palpitasi, nyeri perut, gejala emboli (nyeri dada, hemoptisis dan hemiplegi). Tanda umum yang dapat terjadi distensi vena juguler, takikardi, takipneu, hepatomegali, refluks hepatojugular, asites, edema perifer, perubahan status mental, dan thromboemboli. Tanda kardiak dapat ditemukan ritme gallop, ronki, peningkatan tekanan darah, edema, bising jantung, kardiomegali. ${ }^{3}$

Kriteria diagnosis untuk PPCM. ${ }^{4-6}$

1. Pada pemeriksaan ekokardiografi ditemukan disfungsi sistolik ventrikel kiri yang muncul selama periode peripartum

2. Onset gagal jantung muncul pada bulan terakhir kehamilan atau pada 5 bulan pertama postpartum

3. Tidak adanya penyebab pasti munculnya gagal jantung

4. Tidak adanya penyakit jantung sebelum bulan terakhir kehamilan

Kriteria Ekokardiografi Diagnostik Tambahan.4

1. Ejection fraction $<45 \%$

2. Left ventricular fractional shortening $<30 \%$

3. Left ventricular end diastolic dimension $>2.7$ $\mathrm{cm} / \mathrm{m} 2$ luas permukaan tubuh

\section{Kasus}

Pasien wanita, 43 tahun, ASA III dengan preeklamsi berat pada multigravida hamil preterm belum dalam persalinan dengan PPCM NYHA II riwayat seksio sesarea 10 tahun rencana dilakukan seksio sesaria elektif. Dari pemeriksaan fisik didapatkan pasien komposmentis dengan keadaan umum sedang, tanda vital laju nadi takikardi 110 $\mathrm{x} / \mathrm{menit}$ lain-lain dalam batas normal, saturasi oksigen 95\% dengan masker non-rebreathing (NRM) 6 liter/menit. Pemeriksaan fisik bermakna pada pemeriksaan paru ditemukan ronki basah kasar minimal pada basal kedua lapangan paru, pemeriksaan jantung didapatkan bunyi jantung takikardi dengan bising murmur pansistolik di sela iga IV-V kiri. Tidak didapatkan tanda-tanda ke arah sianosis. Hasil laboratorium didapatkan Hemoglobin $9.7 \mathrm{mg} / \mathrm{dL}$, leukosit $9,500 \mathrm{~mm}$, trombosit $334,000 \mathrm{~mm}$, ureum 0.5 , kreatinin 19 $\mathrm{mg} / \mathrm{dL}$, PT 13.7, APTT 29.2, INR 1.120, natrium $138 \mathrm{mg} / \mathrm{dL}$, kalium $3.1 \mathrm{mg} / \mathrm{dL}$, klorida $104 \mathrm{mg} /$ 


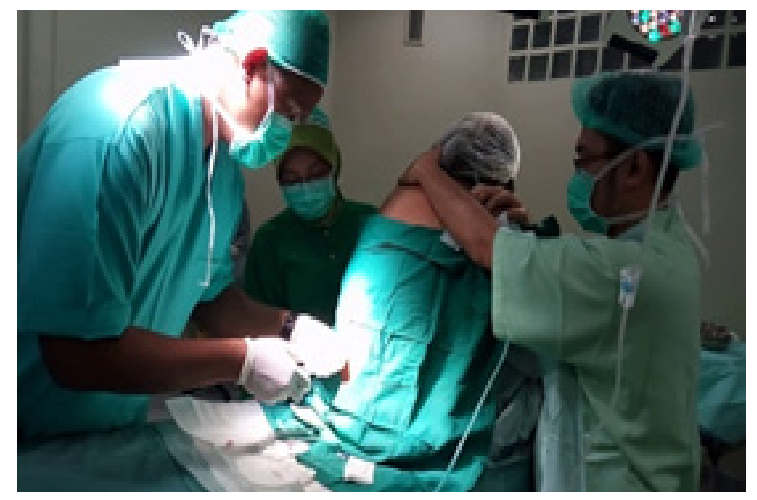

$\mathrm{dL}, \mathrm{pH}$ 7.440, $\mathrm{BE}-4.4, \mathrm{PaCO}_{2} 29, \mathrm{PaO}_{2}$ 78, $\mathrm{HCO}_{3} 22$, Saturasi $\mathrm{O}_{2} 96 \%$.

Elektrokardiografi (EKG) sinus takikardi, HR $110 \mathrm{x} /$ menit dengan hipertrofi ventrikel kiri. Ekokardiografi dimensi ventrikel kiri dilatasi, kontraktilitas ventrikel kiri menurun Ejection Fraction 31\%, fungsi diastolik restriktif. Wall motion global hipokinetik, dimensi atrium kiri dilatasi, atrium kanan dan ventrikel kanan dilatasi. Kontraktilitas ventrikel kanan baik TAPSE 2.9. Katup jantung aorta baik. Katup mitral dengan mitral regurgitasi ringan dengan peak PG 18 mmHg. ${ }^{11}$ Katup pulmonal baik. Teknikanestesi dilakukan regional anestesi dengan epidural murni. Pasien diposisikan dalam posisi duduk, proyeksikan lokasi penusukan (dengan target setinggi L3-Th 10 daerah penusukan pada L2-3). Setelah dilakukan test dose pasien mengeluhkan sesak dan kedua kaki terasa kesemutan. Dilakukan konversi dengan anestesi umum intubasi oral rapid sequence intubation.

Obat induksi digunakan ketamin $30 \mathrm{mg}$, propofol $50 \mathrm{mg}$, fentanyl $50 \mathrm{mcg}$, rocuronium 40mg. Pemeliharaan anestesi digunakan sevofluran 1 vol\%, oksigen 2 liter/menit, airbar 3 liter/ menit, rocuronium intermiten $10 \mathrm{mg}$. Durante operasi hemodinamik pasien relatif stabil. Setelah operasi selesai dirawat diruang ICU menggunakan ventilator mode synchronized mandatory mechanical ventilation (SIMV) dengan seting yang tidak berbeda saat di kamar operasi dan diberikan obat analgetik morfin $10 \mathrm{mcg} / \mathrm{kg} / \mathrm{jam}$. Setelah 5 jam perawatan ICU kondisi pasien stabil dan memenuhi kriteria ekstubasi kemudian dilakukan ekstubasi di ICU.

\section{Pembahasan}

Secara umum, target hemodinamik pada berbagai teknik anestesi adalah sama, yaitu mengurangi kardiak preload dan afterload serta mencegah penurunan kontraktilitas kardiak yang sudah buruk sebelumnya. Teknik anestesi yang menghasilkan penurunan mendadak pada tahanan pembuluh darah sistemik sebaiknya dihindari. Titrasi secara hati-hati baik obat intravena atau anestesi lokal merupakan hal yang penting. Jika memungkinkan, dipasang monitoring invasif terrmasuk tekanan darah dan tekanan vena sentral sebelum memulai anestesi. Tekanan vena sentral memberi informasi pada preload ventrikel kanan tapi tidak memberikan informasi tekanan pada ventrikel kiri. Kateter arteri pulmoner dan ekhokardiografi transesofageal perioperatif digunakan pada pasien dengan fungsi kardiak yang sangat buruk. Ekokardiografi transesofageal yang digunakan durante operasi berguna untuk mengukur perubahan hemodinamik, respon terhadap inotropik dan loading cairan. ${ }^{7-8}$

Regional anestesi (RA) tetap menjadi metode pilihan sebagai simpatektomi yang akan menurunkan kardiak preload dan afterload yang memberi keuntungan pada pasien PPCM. Pada umumnya, RA digunakan pada pasien yang akan menjalani seksio sesaria non emergensi dengan hemodinamik yang relatif stabil dimana pasien dengan gejala moderat atau yang menjalani operasi emergensi digunakan anestesi umum (GA). Spinal anestesi dengan teknik single shot untuk persalinan normal tidak dianjurkan, karena akibat buruknya, seperti henti jantung dan edema paru. Controlled Epidural Analgesi dengan monitoring invasif merupakan metode yang aman dan efektif. Combined Spinal Epidural (CSE) memiliki keuntungan dengan onset cepat dari analgesi spinal dengan opioid short acting serta kateter epidural yang mengatur analgesi dengan konsentrasi rendah dari anestesi lokal dan opioid. Continuous Spinal Anesthesia (CSA) mungkin alternatif yang paling aman, karena fleksibilitas, dosis obat dan kualitas analgesi, tetapi CSA juga memiliki insiden post dural puncture headache 
(PDPH) dan komplikasi neurologi yang tinggi, sehingga sebaiknya digunakan jarum spinal ukuran yang kecil dan menghindari penggunaan Lidocaine hiperbarik. Penggunaan kateter memberikan kebebasan untuk mentitrasi obat anestesi lokal baik pada ruang epidural atau intratekal. Ketinggian blok motorik dan sensorik bisa ditingkatkan secara bertahap sehingga tidak menyebabkan hipotensi mendadak yang mengakibatkan dekompensasi mendadak pada pasien. Pada pasca operasi, RA memberikan keuntungan dan manajemen nyeri yang lebih berkualitas dengan menghindari peningkatan tekanan pembuluh darah sistemik dan laju nadi. ${ }^{9-12}$

GA dipilih pada pasien dengan borderline cardiac decompensation, pada beberapa pasien yang tidak bisa mentoleransi sekecil apapun blokade simpatis yang bisa menyebabkan gagal jantung fulminan serta pada pasien dengan kontraindikasi RA. Pembiusan umum harus dilakukan secara cepat pada wanita hamil untuk menghindari risiko aspirasi yang sangat merugikan pada pasien PPCM. Penggunaan obat nonanestesi intraoperatif harus hati-hati, Ergometrin sebaiknya dihindari dan oksitosin sebaiknya diberikan lewat infus atau dititrasi secara pelan. Autotransfusi setelah persalinan bisa diimbangi dengan pemberian furosemid dosis kecil sesaat sebelum kelahiran bayi. ${ }^{12-13}$

\section{Simpulan}

Manajemen anestesi pada pasien dengan PPCM dapat digunakan baik anestesi regional maupun anestesi umum. Namun tetap mempertimbangkan beberapa faktor salah satunya kondisi pasien dan kemampuan dari dokter anestesi itu sendiri. Yang paling penting adalah apapun pilihan anestesinya tetap prinsip utama harus diperhatikan yaitu kurangi preload dan afterload serta mempertahankan kontraktilitas jantung. Pada kondisi yang darurat ataupun borderline lebih disarankan untuk digunakan teknik anestesi umum.

\section{Daftar Pustaka}

1. Sovndal S, Tabas JA. Cardiovascular disorders in pregnancy. In: Pearlman MD, Tintinalli JE, Dyne PL, editors. Obstetric and Gynecologic Emergencies: Diagnosis and Management. 1st ed. New York: McGrawHill Medical Publishing Division; 2004. $300-9$.

2. Johnson-Coyle L, Jensen L, Sobey A. American College of Cardiology Foundation, American Heart Association. Peripartum cardiomyopathy: Review and practice guidelines. Am J Crit Care. 2012;21:89-98

3. Agboola A. Textbook of obstetrics and gynaecology for medical students. 2nd ed. Ibadan: Heinemann Educational Books plc; 2006. Cardiac disease; 360-4.

4. Cunningham FG, Leveno KJ, Hauth JC, Gilstrap L, III, Bloom SL, Wenstrom KD. Williams Obstetrics. 22nd ed. New York: McGraw-Hill Medical Publishing Division; 2005. Cardiovascular disease; 1017-41.

5. Sliwa K, Fett J, Elkayam U. Peripartum cardiomyopathy. Lancet. 2006;368:687-93.

6. Tawfik LM. Anesthetic and ICU management of peripartum cardiomyopathy. Journal of Obstetric Anaesthesia and Critical Care. 2012.

7. Ro A, Frishman WH. Peripartum cardiomyopathy. Cardiol Rev. 2006;14:3542.

8. Ramaraj R, Sorrell VL. Peripartum cardiomyopathy: causes, diagnosis, and treatment. Cleve Clin J Med. 2009;76:28996.

9. Nelson-Piercy C. Heart disease in pregnancy. In: Edmonds DK, editor. Dewhurst's Textbook of Obstetrics And Gynaecology. 7th ed. UK: Oxford, Blackwell Science Ltd; 2007. 236-45.

10. Goulet B, McMillan T, Bellet S. Idiopathic myocardial degeneration associated with 
pregnancy and especially the Perineum. Am J Med Sci. 1937;194:185-99.

11. Hilfiker-Kleiner D, Sliwa K, Drexler $\mathrm{H}$. Peripartum cardiomyopathy: Recent insights in its pathophysiology. Trends Cardiovasc Med. 2008;18:173-9.

12. Ramachandran R, Rama c handrau R, Rewari $\mathrm{V}$, Trikha A. Anaesthetic management of patients with peripartum cardiomyopathy. Journal of Obstetric Anaesthesia and Critical Care. 2011.

13. Brar SS, Khan SS, Sandhu GK, Jorgensen MB, Parikh N, Hsu JW, et al. Incidence, mortality, and racial differences in peripartum cardiomyopathy. Am J Cardiol. 2007;100:302-4. 